\title{
Uji Daya Berkecambah Pada Benih Turi Putih (Sesbania grandiflora L.)
}

\section{Evaluation Seeds Germination of White Turi Seed (Sesbania grandiflora L.)}

\author{
Jawa Arum Mewangi, Tatiek Kartika Suharsi*, dan Memen Surahman
}

Departemen Agronomi dan Hortikultura, Fakultas Pertanian, Institut Pertanian Bogor (Bogor Agricultural University), Jl. Meranti, Kampus IPB Darmaga, Bogor 16680, Indonesia Telp. \& Faks.62-251-8629353 e-mail agrohort@apps.ipb.ac.id

*Penulis Korespondensi : t.suharsi@yahoo.co.id

Disetujui : 20 September 2018 / Published Online 06 Mei 2019

\begin{abstract}
Turi is one of horticultural plant has many benefits but its existence is increasingly limited. Development of turi should begin with the procurement of high quality seed. Test power germinated is one test used to detect the seeds. Germination of seed resource test procedure is not yet well known as turi methods break dormancy, germination substrates that are effective, as well as the first count and final count so that research needs to be done. The research was carried out in a Laboratory Storage and Seed Quality Testing of IPB in MaySeptember 2017. That test results obtained from the seeds of turi germination for 21 days is the first count on day 6 and final count on day 8. The most maximum germination substrate is merang paper then filter paper. Turi also have dormancy so need to be given preferential treatment so that the dormancy was broken and easy to germinate. Scarification (sandpaper) method is the best method in breaking seed dormancy of turi.
\end{abstract}

Keywords: final count, first count, merang paper, sandpaper

\begin{abstract}
ABSTRAK
Turi merupakan salah satu tanaman hortikultura yang memiliki banyak manfaat namun keberadaannya semakin terbatas. Pengembangan tanaman turi harus dimulai dengan pengadaan benih yang bermutu tinggi. Uji daya berkecambah adalah salah satu pengujian yang digunakan untuk mendeteksi benih. Prosedur pengujian daya berkecambah benih turi belum banyak diketahui seperti metode pematahan dormansi, substrat perkecambahan yang efektif, serta first count dan final count sehingga perlu dilakukan penelitian. Penelitian ini dilaksanakan di Laboratorium Penyimpanan dan Pengujian Mutu Benih IPB pada bulan MeiSeptember 2017. Hasil pengujian yang diperoleh dari pengecambahan benih turi selama 21 hari adalah hitungan pertama (first count) nya pada hari ke-6 dan hitungan kedua (final count) pada hari ke-8. Substrat perkecambahan yang paling optimum untuk mengecambahkan benih turi adalah kertas merang kemudian kertas saring. Turi juga memiliki dormansi sehingga perlu diberikan perlakuan supaya dormansinya patah dan mudah untuk berkecambah. Metode skarifikasi (pengamplasan) adalah metode terbaik dalam mematahkan dormansi benih turi.
\end{abstract}

Kata kunci: amplas, hitungan kedua, hitungan pertama, kertas merang 


\section{PENDAHULUAN}

Turi (Sesbania grandiflora) merupakan salah satu tanaman kacang-kacangan asli Indonesia. Turi termasuk dalam famili Papilionaceae. Ada dua jenis turi berdasarkan warna bunganya yaitu turi merah dan turi putih. Tanaman turi memiliki banyak manfaat. Towaha dan Rusli (2010) menyatakan bahwa tanaman turi sangat bermanfaat bagi manusia. Bunganya banyak mengandung vitamin. Biji turi juga memiliki kandungan kimia yaitu kalsium oksalat, sulfur, kalium, natrium, beta karoten, vitamin A, vitamin B serta zat besi yang bermanfaat bagi tubuh.

Tanaman turi jumlahnya tergolong jarang di Indonesia dan pemanfaatannya pun belum optimal. Menurut Duwianta dan Yusuf (2012), benih turi termasuk benih ortodoks yang bisa disimpan menggunakan wadah yang disegel dengan suhu simpan $\pm 4{ }^{\circ} \mathrm{C}$. Selain itu menurut Evan and Rotar (1987) menyatakan bahwa benih turi (Sesbania grandiflora) akan kehilangan viabilitasnya setelah dilakukan penyimpanan selama 2 tahun. Selain itu, tanaman turi juga berkhasiat untuk obat diantaranya berperan dalam penyembuhan penyakit disentri, pereda nyeri, dan keputihan. Sejauh ini informasi ilmiah mengenai tanaman turi masih sangat terbatas, hal ini patut disayangkan karena tanaman ini memiliki manfaat/khasiat yang baik untuk kesehatan dan berperan cukup besar dalam pemenuhan kebutuhan konsumsi masyarakat.

Benih turi merupakan benih legum yang benihnya tergolong ke dalam benih keras. Adanya benih keras tersebut mengakibatkan benih mengalami dormansi fisik. Dormansi fisik ini dapat menyebabkan pembatas struktural terhadap perkecambahan. Menurut Argel dan Paton (1999) beberapa metode pematahan dormansi telah digunakan untuk mengatasi permasalahan dormansi kulit benih pada legum, di antaranya skarifikasi mekanik, kimia, dan perlakuan air panas pada suhu konstan dan suhu berganti.

Pengembangan turi di Indonesia tidak mengalami perkembangan yang pesat karena terkendala oleh minimnya jumlah benih turi yang bermutu. Benih bermutu tinggi dapat berkecambah dengan baik ketika ditanam di lapangan sehingga dapat meningkatkan efisiensi dan mutu/kualitas hasil produksi. Menurut ISTA (2014), media untuk pengujian daya berkecambah benih adalah media kertas dan media pasir. ISTA merekomendasikan media kertas berupa kertas saring dan kertas blotter untuk pengecambahan benih walaupun terdapat kendala diantaranya harga yang cukup mahal dan ketersediaan yang terbatas.

Prosedur terhadap penelitian benih turi pun masih jarang dilakukan. Teknik pematahan dormansi benih yang paling efektif, substrat perkecambahan yang optimum, serta first count (hitungan pertama) dan final count (hitungan kedua) belum pernah diteliti sebelumnya. Oleh karena itu perlu dilakukan penelitian untuk menjawab berbagai permasalahan tersebut. Harapannya dengan adanya penelitian ini dapat dihasilkan benih yang bermutu tinggi dan ketika ditanam mampu tumbuh normal dan menghasilkan produksi yang maksimum sehingga pemenuhan kebutuhan manusia akan tercapai dengan baik.

\section{BAHAN DAN METODE}

Penelitian dilaksanakan di Laboratorium Pengujian Mutu Benih dan Penyimpanan Benih, Departemen Agronomi dan Hortikultura, Fakultas Pertanian, Institut Pertanian Bogor, pada bulan Mei 2017 sampai dengan September 2017. Bahan yang digunakan dalam penelitian ini adalah benih turi yang diperoleh dari kebun di Desa Ngadirojo, Kabupaten Ponorogo, Provinsi Jawa Timur. Substrat perkecambahan yang digunakan meliputi kertas merang, kertas cd buram, kertas saring (kontrol), dan pasir. Bahan lain yang digunakan adalah asam sulfat $\left(\mathrm{H}_{2} \mathrm{SO}_{4}\right) 1 \%$, natrium hipoklorit $(\mathrm{NaClO}) 0.5 \%$, air panas, aquades, alkohol, label, amplop kertas, dan selotip. Alat yang digunakan adalah alat pengecambah benih tipe IPB 72-1, termometer, oven, termos air, stoples kaca, bak pasir, timbangan 4 digit, wadah plastik untuk mengecambahkan benih, dan alat tulis.

Penelitian ini dibagi ke dalam 2 percobaan. Percobaan 1, menentukan first count dan final count serta mengetahui pengaruh substrat perkecambahan yang optimum dalam pengujian daya kecambah benih turi putih. Penentuan first count dan final count dapat diketahui dengan cara menghitung kecambah normal setiap hari selama 21 hari. Pengujian substrat perkecambahan dilakukan dengan menggunakan rancangan acak lengkap (RAL) faktor tunggal. Faktor substrat perkecambahan terdiri atas empat jenis yaitu kertas merang (M1), kertas cd buram (M2), pasir (M3), dan kertas saring (kontrol). Setiap perlakuan terdiri atas 4 ulangan sehingga terdapat 16 satuan percobaan. Benih yang digunakan untuk setiap satuan percobaan adalah 25 butir benih.

Percobaan 2, pematahan dormansi benih turi putih meliputi kontrol, amplas, perendaman dengan air panas, dan perendaman pada larutan asam sulfat $\left(\mathrm{H}_{2} \mathrm{SO}_{4}\right)$. Rancangan percobaan yang 
digunakan adalah rancangan kelompok lengkap teracak (RKLT) dengan 4 perlakuan dan 4 ulangan sehingga terdapat 16 satuan percobaan.Benih yang digunakan untuk setiap ulangan adalah 20 butir benih.

Data percobaan pertama diolah menggunakan Microsoft Excel untuk analisis grafik sehingga diperoleh first count dan final count serta substrat perkecambahan yang optimum. Percobaan kedua dianalisis menggunakan uji $\mathrm{F}$, hasilnya berpengaruh nyata maka dilanjutkan dengan menggunakan uji dunnet pada taraf 5\%. Kedua percobaan tersebut dianalisis menggunakan software SAS 9.1.

Percobaan 1, benih disortasi terlebih dahulu sebelum dikecambahkan agar diperoleh benih yang seragam. Benih yang telah disortasi kemudian diukur kadar airnya menggunakan metode oven yang bersuhu rendah yaitu ditimbang M1 (bobot cawan), M2 (bobot cawan+benih), dan M3 (bobot cawan+benih setelah di oven). Suhu yang digunakan adalah $103{ }^{\circ} \mathrm{C}$ dengan waktu 17 jam. Rumus kadar air adalah:

$$
\mathrm{KA}=\frac{\mathrm{M} 2-\mathrm{M} 3}{\mathrm{M} 2-\mathrm{M} 1}
$$

Pengujian daya berkecambah menggunakan 400 butir benih turi pada 4 substrat pengecambahan yang berbeda yaitu kertas saring, kertas buram, kertas saring, dan pasir. Pengecambahan dilakukan dengan menggunakan metode penanaman yaitu uji kertas digulung didirikan dilapisi plastik (UKDdp). Benih yang ditanam sebanyak 25 butir pada setiap gulung. Benih ditanam pada 4 substrat pengecambahan yang terlebih dahulu telah dilembabkan menggunakan aquades dan kemudian ditiriskan. Sebelum ditanam, benih direndam terlebih dahulu menggunakan Natrium Hipoklorit $(\mathrm{NaClO})$ selama 15 menit. Pemberian $\mathrm{NaClO}$ ini untuk sterilisasi permukaan benih dari cendawan, bakteri, dan lain-lain. Setelah ditanam, benih dikecambahkan pada alat pengecambah benih tipe IPB 72-1 kecuali substrat pasir.

Pengecambahan untuk perlakuan substrat pasir dilakukan dengan metode top of sand, yaitu mengecambahkan benih hanya dengan menekan di permukaan media. Pengecamabahan dilakukan di luar ruangan mengunakan bak pasir. Pengamatan dilakukan dengan mengamati jumlah kecambah normal yang tumbuh sebagai penentuan first count dan final count. Pengamatan dilakukan setiap hari selama 21 hari.

Percobaan 2, pematahan dormansi dilakukan dengan cara skarifikasi yaitu mekanis, fisik, dan kimia. Perlakuan yang digunakan sebanyak empat taraf yaitu kontrol (tanpa skarifikasi), amplas, perendaman pada air panas, dan perendaman dengan larutan $\mathrm{H}_{2} \mathrm{SO}_{4} \quad 1 \%$. Media yang digunakan untuk pematahan dormansi adalah media yang paling optimum hasil dari percobaan 1. Cara mekanis yaitu mengamplas benih sebanyak 5 kali gosokan tanpa mengenai tempat titik tumbuh benih. Cara fisik yaitu merendam benih di air panas dengan suhu $60{ }^{\circ} \mathrm{C}$ selama 15 menit sedangkan cara kimia dengan merendam benih dalam $\mathrm{H}_{2} \mathrm{SO}_{4} 1 \%$ selama 30 menit. $\mathrm{H}_{2} \mathrm{SO}_{4}$ sebesar 5 gram terlebih dahulu dilarutkan dalam $1 \mathrm{~L}$ aquades kemudian direndam dalam larutan $\mathrm{H}_{2} \mathrm{SO}_{4}$ selama 30 menit. Sebelum penanaman, benih direndam terlebih dahulu menggunakan natrium hipoklorit $(\mathrm{NaClO})$. Benih dikecambahkan pada alat pengecambah benih IPB 72-1.

Pengamatan yang dilakukan pada percobaan ini meliputi pengamatan viabilitas total yaitu potensi tumbuh maksimum (PTM), viabilitas potensial yaitu daya berkecamabah (DB) benih dan berat kering kecambah normal (BKKN), serta vigor benih yaitu kecepatan tumbuh (Kct).

1. Potensi tumbuh maksimum (PTM)

PTM dihitung berdasarkan jumlah kecambah normal pada hitungan pertama dan jumlah kecambah normal serta abnormal pada hitungan kedua. Rumusnya :

$$
\text { PTM }=\frac{\text { Kecambah normal+Kecambah abnormal }}{\text { Jumlah total benih yang ditanam }} \times 100 \%
$$

2. Daya berkecambah (DB)

$$
\mathrm{DB}=\frac{\sum \mathrm{KNI}+\sum \mathrm{KNII}}{\text { Jumlah benih yang ditanam }} \times 100 \%
$$

3. Berat kering kecambah normal (BKKN)

Berat kering kecambah normal dihitung dengan cara mengeringkan seluruh kecambah normal yang terdapat pada hitungan pertama dan kedua kemudian dikeringkan menggunakan oven dengan suhu $60{ }^{\circ} \mathrm{C}$ selama 3 x 24 jam.

4. Kecepatan tumbuh (Kct)

Kecepatan tumbuh (Kct) dihitung berdasarkan jumlah kecambah normal yang dapat tumbuh setiap satu etmal (24 jam), dengan rumus: $\mathrm{Kct}=\sum \% \mathrm{Kecambah}$ normal $/$ etmali $=\mathrm{n} 1=0$

\section{HASIL DAN PEMBAHASAN}

\section{Kondisi Umum Percobaan}

Benih turi yang digunakan merupakan benih lokal yang berasal dari Desa Ngadirojo, Kabupaten Ponorogo, Provinsi Jawa Timur. Benih turi berwarna coklat dengan bentuknya sedikit lonjong (Gambar 1). Benih yang digunakan diambil langsung dari kebun seorang petani pada 
bulan Juli tahun 2017. Benih diambil langsung dari pohonnya dalam bentuk polong. Polong dijemur terlebih dahulu. Setelah kering langsung dikupas dan diambil benihnya. Kadar air benih harus tetap dijaga agar tetap bagus sehingga sebelum ditanam, benih disimpan terlebih dahulu di dalam ruang penyimpanan benih.
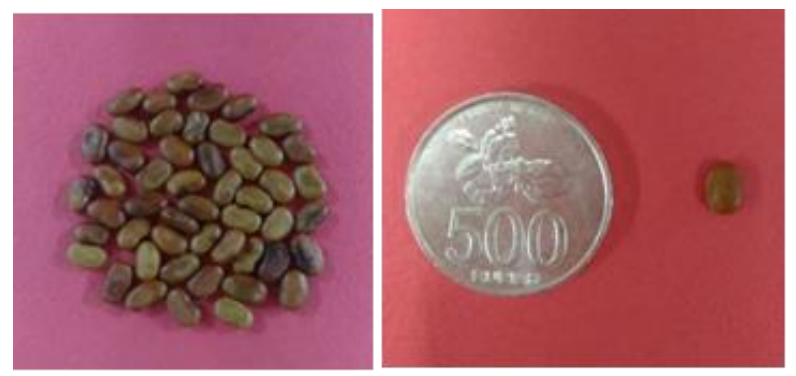

Gambar 1. Keragaan benih turi putih lokal Ponorogo

Pengamatan kadar air benih dilakukan sebelum penyimpanan. Ketika benih datang langsung dilakukan pengamatan. Hasil pengamatan menunjukkan bahwa rata-rata kadar air benih turi sebesar $11.9 \%$. Kondisi ini merupakan kondisi yang aman untuk penyimpanan benih turi yang tergolong benih ortodoks. Menurut Indartono (2011) pada benih kedelai yang tergolong ortodoks, benih yang memiliki kadar air di atas 13\% akan mengalami kemunduran lebih cepat. Sebagian besar benih mengalami kadar air optimum penyimpanan 6$11 \%$.

Selain pengamatan kadar air, daya berkecambah benih turi pada pengujian awal juga diamati. Hasil menunjukkan bahwa daya berkecambah benih sebesar 69\%. Hal ini dikategorikan daya berkecambah benih rendah karena standar daya berkecambah untuk hampir seluruh benih adalah $\geq 80 \%$. Daya berkecambah benih yang rendah ini disebabkan oleh adanya dormansi benih sehingga proses imbibisinya terhambat. Selain itu, munculnya cendawan yang kemungkinan disebabkan mikroorganisme yang terbawa benih baik itu saat pengambilan benih maupun karena alat atau substrat perkecambahannya. Setelah dilakukan pengamatan kadar air dan daya berkecambah benih turi, selanjutnya benih disimpan pada ruang penyimpanan untuk selanjutnya dilakukan penelitian.

\section{Penentuan First Count dan Final Count serta Substrat Perkecambahan yang Optimum dalam Uji Daya Berkecambah Benih Turi Putih}

Pengujian daya berkecambah benih turi putih dilakukan pada eco germinator yaitu alat pengecambah IPB 72-1. Pengujian ini dilakukan untuk mendapatkan hasil hitungan pertama (first count) dan hitungan kedua (final count). Menurut ISTA (2014) pengujian daya berkecambah menggunakan eco germinator pada suhu ruang menyebabkan perkembangan kecambah lebih cepat dibandingkan dengan yang lain. Tujuan hitungan pertama (first count) adalah untuk menghitung jumlah kecambah yang sudah normal dan juga dilakukan pengamatan utuk kecambah yang terserang penyakit. Hitungan kedua (final count) adalah keadaan dimana semua benih yang viabel telah menunjukkan mampu berkecambah secara optimum. Selain diamati kecambah normal dan yang terserang penyakit, kecambah abnormal juga diamati saat hitungan kedua ini.

Pengujian untuk penentuan first count dan final count ini menggunakan 25 butir benih untuk setiap lot benih. Substrat atau media yang digunakan untuk mengecambahkan berbeda-beda. Hal ini dilakukan untuk mengetahui substrat yang paling optimum dari 4 substrat yang digunakan pada perkecamabahan benih turi. Substrat tersebut meliputi kertas merang, kertas saring, kertas buram, dan pasir. Setelah benih ditanam, semua media yang menggunakan kertas dimasukkan ke alat pengecambah benih IPB 72-1 sedangkan untuk pasir benih dikecambahkan pada bak pasir dan diletakkan di luar ruangan. Selain substrat yang berbeda, perlakuan yang diberikan pun berbeda yaitu diberi perlakuan skarifikasi (amplas) dan tanpa skarifikasi. Hal ini dilakukan berdasarkan hasil dari uji daya berkecambah awal benih setelah benih datang. Daya berkecambahnya rendah karena kemungkinan adanya dormansi pada benih sehingga dormansi perlu dipatahkan agar benih dapat tumbuh lebih maksimum.

Kriteria kecambah normal merupakan indikator penting untuk penentuan periode (hari) pengamatn. Ciri kecambah normal pada benih turi adalah apabila benih telah memiliki kotiledon utuh, hipokotil dan akar panjangnya minimal dua kali dari ukuran kotiledon. (Gambar 2a). Kecambah dikategorikan abnormal apabila struktur kecambah tidak lengkap, panjang akar dan hipokotil kurang dari dua kali panjang kotiledon (Gambar 2b). Kecambah turi ada juga yang berpenyakit (Gambar 2c). Ciri kecambah

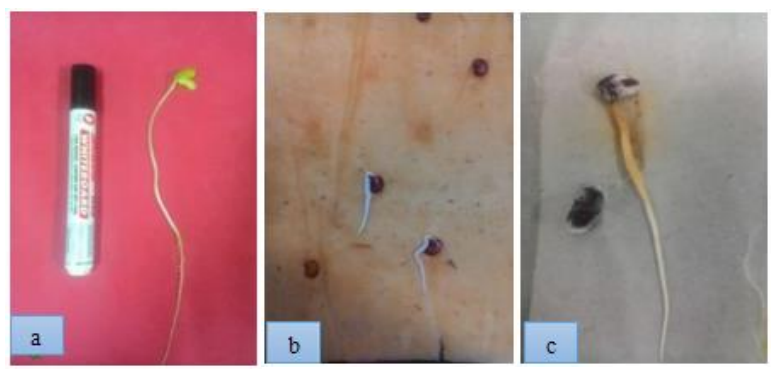

Gambar 2. Kriteria kecambah benih turi putih. Keterangan: a) kecambah normal; b) 
kecambah abnormal; c) kecambah terserang penyakit.

berpenyakit di antaranya kecambah terlihat rusak pada bagian tertentu seperti kotiledon, hipokotil, atau bagian yang lain. Selain itu, terdapat bercakbercak bahkan warnanya dapat berubah seperti kecoklatan.

Hasil pengamatan dengan perlakuan skarifikikasi menunjukkan bahwa setelah benih dikecambahkan selama 21 hari, kecambah normal baru muncul pada hari ke-5 namun jumlahnya baru sedikit. Kecambah normal terbanyak terdapat pada hari ke-6. Kemudian kecambah muncul cukup banyak lagi pada hari ke-8 namun lebih jumlah ini lebih sedikit dari hari ke-6. Jumlah kecambah normal terus mengalami penurunan pada hari ke-9 hingga hari ke-21. Secara keseluruhan dapat disimpulkan bahwa hitungan pertama (first count) benih turi adalah hari ke-6 sedangkan hitungan kedua (final count) adalah hari ke-8 (Gambar 3).

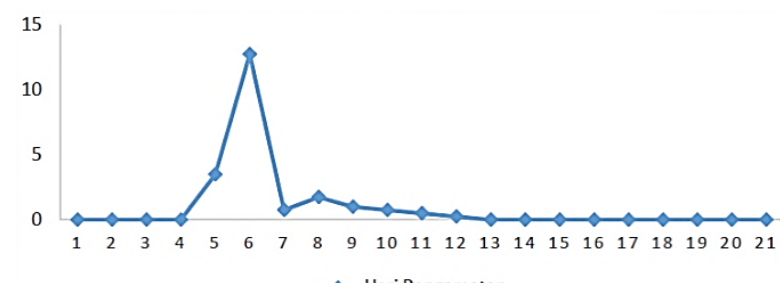

Gambar 3. Jumlah kecambah normal harian selama 21 hari pengamatan dengan perlakuan skarifikasi

Daya berkecambah benih tanpa perlakuan skarifikasi menunjukkan hasil yang kurang maksimal. Hal ini dipengaruhi adanya dormansi benih atau benih dalam kondisi istirahat. Selain karena dormansi, benih turi tergolong benih yang cukup keras sehingga benih sulit melakukan imbibisi dan mengakibatkan proses berkecambahnya terhambat (Gambar 4).

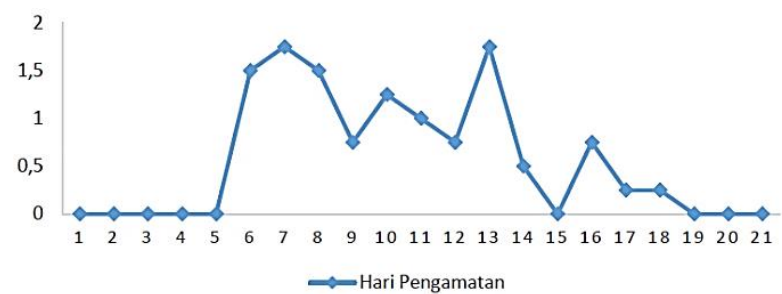

Gambar 4. Jumlah kecambah normal harian selama 21 hari pengamatan tanpa perlakuan skarifikasi

Berdasarkan grafik 3 dan 4, dapat disimpulkan bahwa benih turi akan maksimal melakukan perkecambahan apabila diberikan perlakuan skarifikasi. Perlakuan skarifikasi akan mengubahah atau mengikis kondisi kulit benih yang keras sehingga benih dapat dengan mudah menyerap air dan gas saat proses perkecambahan. Menurut Rahmasyahraini (2008) skarifikasi adalah cara yang efektif untuk meningkatkan perkecambahan benih meskipun terkadang benih yang diskarifikasi akan mudah rusak karena serangan patogen.

Substrat perkecambahan yang tepat sangat mempengaruhi mutu benih. Selain itu, dengan adanya substrat akan memudahkan suplai air saat perkecambahan. Menurut Sadjad (1980) media dan kondisi lingkungan harus optimal saat perkecambahan agar dapat memenuhi segala sesuatu yang diperlukan benih sehingga sesuai dan merepresentasikan pertumbuhan dari benih pada kondisi lapang yang optimum. Pengamatan daya berkecambah ini menggunakan 4 perlakuan substrat perkecambahan yang berbeda-beda. Substrat tersebut meliputi kertas saring, kertas merang, kertas buram, dan pasir. Hasil menunjukkan bahwa substrat memberikan pengaruh yang sangat nyata terhadap pertumbuhan kecambah benih turi kecuali pada substrat pasir. Substrat pasir menunjukkan pengaruh yang tidak nyata.

Kertas merang, kertas saring, dan kertas buram memberikan pengaruh yang sangat nyata terhadap petumbuhan kecambah benih. Hasil menunjukkan bahwa substrat perkecambahan yang paling optimum tertinggi adalah kertas merang (Gambar 5). Daya berkecambah juga optimum apabila menggunakan substrat perkecambahan yang optimum. Menurut Purdyaningsih (2015) pemanfaatan kertas merang secara luas saat ini masih menemui kendala namun untuk pengujian daya berkecambah benih telah banyak dilakukan pada komoditas perkebunan. Kertas merang ini memiliki daya serap air yang jauh lebih baik dibandingkan dengan kertas lain.

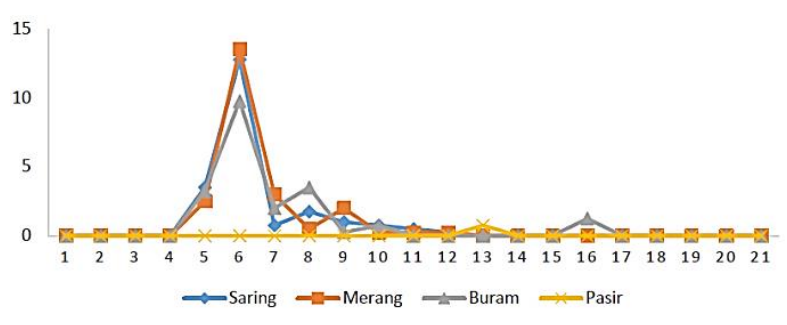

Gambar 5. Tingkat pertumbuhan kecambah benih turi menggunakan beberapa substrat perkecambahan

Kertas saring juga memberikan pengaruh yang bagus jika digunakan untuk perkecambahan turi. ISTA (2014) merekomendasikan media kertas berupa kertas saring dan kertas blotter untuk pengecambahan benih walaupun terdapat kendala diantaranya harga yang cukup mahal dan ketersediaan yang terbatas. Berdasarkan hasil analisis, kertas buram berbeda nyata lebih rendah dari kertas saring. Kertas buram ini bisa dijadikan 
sebagai substrat alternatif dalam pengujian daya berkecambah benih turi. Hal ini sejalan dengan penelitian Purdyaningsih (2015) pada perkecambahan benih wijen yang menunjukkan bahwa kertas merang dan kertas buram mampu menghasilkan daya berkecambah yang tinggi karena mampu menahan air yang cukup selama periode pengujian benih. Selain itu menurut Rahayu (2015) pada penelitian perkecambahan benih kecipir menyatakan bahwa kertas buram cukup mampu mempertahankan kelembaban dan mempu mempertahankan air agar tidak banyak yang hilang.

Substrat yang memiliki daya berkecambah terendah adalah pasir. Pertumbuhan benih berlangsung lama ketika dikecambahkan pada media pasir dan bahkan banyak yang terkena penyakit. Hal ini terjadi kemungkinan disebabkan oleh bentuk benih yang terlalu kecil sehingga kurang cocok apabila ditanam di pasir. Selain itu, medianya kurang steril dan kurangnya kemampuan pasir untuk menjaga kelembaban air sehingga menghambat pertumbuhan kecambah benih turi. Menurut Direktorat Jenderal Tanaman Pangan dan Hortikultura (2006) media perkecambahan benih itu harus memilki kemampuann untuk menahan air, bersih dan bebas dari bakteri, cendawan maupun zat beracun lainnya sedangkan untuk media pasir dan tanah harus dalam keadaan yang steril sebelum digunakan. Hasil perbandingan kecambah normal turi putih untuk substrat kertas merang, kertas saring, kertas buram, dan pasir dapat dilihat pada Gambar 6.

\section{Pematahan Dormansi Benih}

Benih turi memiliki daya berkecambah yang rendah apabila dikecambahkan tanpa diberi perlakuan misalnya tanpa skarifikasi. Hal ini disebabkan benih turi memiliki dormansi. Benih turi di Ponorogo memiliki tingkat dormansi sekitar 40\%. Dormansi benih ini akan menghambat proses imbibisi ke dalam benih sehingga benih tumbuh tidak serempak. Oleh karena itu, perlu diberikan perlakuan untuk mematahkan dormansinya. Menurut Widhityarini et al (2011), perlakuan pematahan dormansi dilakukan untuk mempercepat perkecambahan benih sehingga presenase berkecambahnya tetap tinggi. Pemberian perlakuan ini diberikan pada benih-benih yang memiliki tingkat kesulitan tinggi untuk dikecambahkan.

Hasil penelitian menunjukkan bahwa pematahan dormansi yang dilakukan terhadap benih turi memberikan pengaruh yang sangat nyata terhadap daya berkecambah dan berat kering kecambah normal serta berpengaruh nyata pada potensi tumbuh maksimum. Hasil tidak berpengaruh nyata pada kecepatan tumbuh (Kct). (Tabel 1) Adanya pengaruh tersebut sesuai dengan penelitian Azad et al. (2012) yang menyatakan bahwa perlakuan sebelum tanam akan mempengaruhi tingkat perkecambahan suatu benih. Apabila perlakuannya tepat akan semakin memudahkan untuk perkecambahan benih.

Tabel 1. Nilai rataan tolok ukur viabilitas benih pada masing-masing perlakuan pematahan dormansi

\begin{tabular}{lclll}
\hline Perlakuan & $\begin{array}{c}\text { Kct } \\
(\% \text { etmal } \\
1\end{array}$ & $\begin{array}{c}\text { PTM } \\
(\%)\end{array}$ & $\begin{array}{l}\text { DB } \\
(\%)\end{array}$ & $\begin{array}{c}\text { BKKN } \\
(\mathrm{g})\end{array}$ \\
\hline Amplas & 2.23 & $96.25^{* *}$ & $87.5^{* *}$ & $31.21^{* *}$ \\
$\mathrm{H}_{2} \mathrm{SO}_{4}$ & 1.56 & 37.5 & 28.75 & 30.98 \\
Air Panas & 1.92 & 43.75 & 21.25 & 30.97 \\
Kontrol & 2.03 & 41.25 & 25 & 30.95 \\
\hline
\end{tabular}

Keterangan : $* *=$ sangat berbeda nyata terhadap perlakuan kontrol (tanpa perlakuan pematahan dormansi) berdasarkan hasil uji t-dunnet pada taraf $5 \%$. PTM = Potensi Tumbuh Maksimum, DB = Daya Berkecambah, BKKN = Berat Kering Kecambah Normal, Kct $=$ Kecepatan Tumbuh

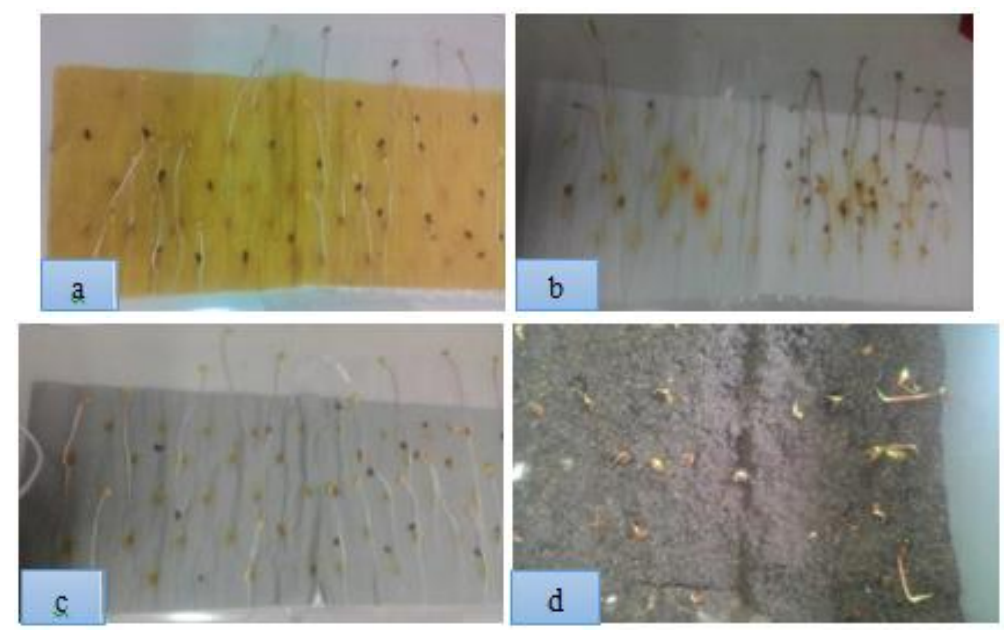

Gambar 6. Perbandingan kecambah normal yang tumbuh pada beberapa substrat perkecambahan Keterangan: substrat a) merang; b) saring; c) buram; d) pasir. 
Perlakuan kecepatan tumbuh tidak memberikan pengaruh nyata terhadap perkecambahan benih turi (Tabel 1). Hal ini disebabkan kemungkinan perhitungan waktu yang kurang tepat. Selain itu banyaknya penyakit yang tumbuh pada saat perkecambahan sehingga benih mati pun semakin banyak. Hal ini sejalan dengan Lesilolo et al (2015) bahwa kecepatan tumbuh benih merupakan proses reaktivasi benih cepat apabila kondisi sekeliling untuk tumbuh optimum dan proses metabolisme tidak terhambat. Kecepatan tumbuh dapat diungkapkan sebagai tolok ukur waktu yang diperlukan untuk mencapai perkecambahan satu etmal. Perkecambahan satu etmal yaitu selama 24 jam.

Daya berkecambah tertinggi dihasilkan dari perlakuan menggunakan amplas yaitu sebesar $87.5 \%$. Skarifikasi menggunakan amplas dilakukan dengan cara menggosok benih sebanyak 5 kali pada punggungnya tanpa mengenai hilum (titik tumbuh benih). Pengamplasan benih akan memudahkan air masuk ke dalam benih karena kulit benih yang tidak lagi keras atau tipis. Proses imbibisipun berlangsung dengan mudah sehingga banyak benih yang mampu tumbuh dengan serempak. Perlakuan pematahan dormansi dengan $\mathrm{H}_{2} \mathrm{SO}_{4}$ $1 \%$ selama 30 menit dan air panas suhu $60{ }^{\circ} \mathrm{C}$ selama 15 memberikan hasil yang tidak berbeda nyata dengan kontrol. Hal ini menunjukkan bahwa perlakuan selain pengamplasan belum mampu menghasilkan daya berkecambah yang lebih baik dari pengamplasan.

Benih yang memiliki bobot kering kecambah normal tertinggi juga dihasilkan dari perlakuan pengamplasan yaitu sebesar $31,21 \%$. Produksi bobot kering dari pertumbuhan kecambah mencerminkan kondisi fisiologis benih. Kecambah dengan bobot kering yang tinggi merupakan indikasi bahwa benih tersebut bervigor tinggi. Hasil BKKN untuk ketiga perlakuan yang lain menunjukkan hasil yang hampir sama yaitu sekitar 30\%. Potensi tumbuh maksimum tertinggi dicapai pada perlakuan pengamplasan sedangkan perlakuan yang lain pun tidak berbeda nyata dengan kontrol.

Perlakuan $\mathrm{H}_{2} \mathrm{SO}_{4} \quad 1 \%$ selama 30 menit tidak memberikan pengaruh yang baik bagi indicator perkecambahan benih karena kemungkinan konsentrasi larutan yang digunakan terlalu tinggi sehingga merusak embrio benih. Menurut Kemenhut (2012) asam $\mathrm{H}_{2} \mathrm{SO}_{4}$ menyebabkan kerusakan pada kulit biji legum maupun non legum apabila konsentrasinya tidak tepat sehingga perlu dicari konsentrasi yang tepat untuk masing-masing benih. Yuniarty (2015) perlakuan kimia dengan $\mathrm{H}_{2} \mathrm{SO}_{4}$ pada prinsipnya adalah membuang lapisan lilin pada kulit benih yang keras dan tebal sehingga benih kehilangan lapisan yang permeabel terhadap gas dan air sehingga meabolisme dapat berjalan dengan baik.

Perlakuan air panas suhu $60{ }^{\circ} \mathrm{C}$ selama 15 menit juga memberikan hasil yang kurang efektif pada indikator perkecambahan karena kemungkinan perendaman benih terlalu lama. Menurut Lima (2012) pada penelitiannya tentang legum menyatakan bahwa perendaman benih yang paling efektif pada benih Leguminosa Centro dan Siratro adalah selama 10 menit karena baik untuk mencegah benih dari kerusakan embrionya. Perendaman selama 15 menit mengakibatkan kerusakan pada embrio benih tersebut sehingga daya berkecambahnya rendah.

Kecambah normal yang dihasilkan dari perlakuan amplas memiliki morfologi yang lebih bagus dibandingkan dengan perlakuan yang lain. Perbandingan kecambah normal benih turi dari beberapa perlakuan tersebut dapat dilihat pada Gambar 7.

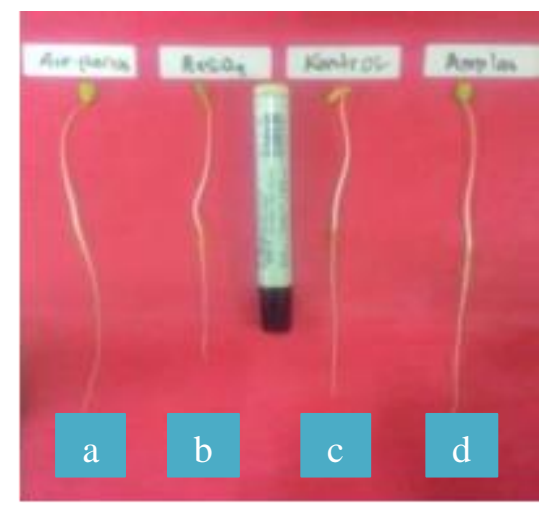

Gambar 7. Perbandingan kecambah normal pada beberapa perlakuan pematahan dormansi benih. Keterangan: a) air panas; b) kontrol; c) $\mathrm{H}_{2} \mathrm{SO}_{4}$; d) amplas.

Berdasarkan penjelasan di atas, perlakuan pengamplasan memberikan pengaruh yang paling baik terhadap seluruh indikator perkecambahan yaitu daya berkecambah, potensi tumbuh maksimum, berat kering kecambah normal, maupun kecepatan tumbuh. Hal ini menunjukkan bahwa perlakuan pengamplasan merupakan cara yang paling efektif untuk mematahkan dormansi pada benih turi. Hal ini sejalan dengan Hasbianto (2013) menyatakan bahwa teknik pematahan dormansi dengan skarifikasi (pengamplasan) memberikan hasil yang paling efektif pada perkecambahan jarak kepyar karena tidak membuat embrionya rusak selama metodenya tepat. 


\section{KESIMPULAN}

Hitungan pertama (first count) dan hitungan kedua (final count) benih turi terjadi pada hari ke-6 dan ke-8 dengan jangka waktu pengamatan selama 21 hari. Substrat perkecambahan yang paling optimal untuk mengecambahkan benih turi adalah kertas merang selanjutnya kertas saring. Benih turi tidak mampu berkecambah dengan optimal pada media pasir karena bentuk benih yang terlalu kecil sehingga kurang cocok apabila ditanam di pasir. Benih turi memiliki dormansi sehingga apabila dikecambahkan tanpa perlakuan, daya berkecambahnya rendah. Perlakuan yang paling efektif untuk mematahkan dormansi benih turi adalah dengan metode skarifikasi (pengamplasan).

\section{DAFTAR PUSTAKA}

Argel, P.J., C.J. Paton. 1999. Forage seed production 2nd ed. Dalam Loch DS dan Ferguson JE (eds.). Tropical and Subtropical species. CABI Publishing. Wallingford.

Direktorat Jenderal Tanaman Pangan dan Hortikultura. 2006. Pedoman Laboratorium Pengujian Mutu Benih Tanaman Pangan dan Hortikultura. Departemen Pertanian.

Duwianta, H. Yusuf. 2012. Informasi Singkat Benih Turi (Sesbania grandiflora). Badan Perbenihan Tanaman Hutan. Sulawesi.

Evan, O.D., P.P. Rotar. 1987. Sesbania in Agriculture. Westview Press. London

Hasbianto, A., C. Tresniawati. 2013. Efektivitas teknik pematahan dormansi pada beberapa genotipe jarak kepyar (Ricinus communis L.). Seminar Nasional Inovasi Teknologi Pertanian. Kalimantan Selatan.

[ISTA] International Seed Testing Association. 2014. International Rules for Seed Testing. ISTA. Switzerland.

Kemenhut. 2012. Pedoman Penanganan Benih Hutan Tropis. BPTH Sulawesi. Makassar.

Lesilolo, M.K., J. Petty, N. Tetty. 2015. Penggunaan desikan abu dan lama simpan terhadap kualitas benih jagung (Zea mays L.) pada penyimpanan ruang terbuka. Jurnal Agrologia. 1(1):51-59.

Lima, D. 2012. Pengaruh waktu perendaman dalam air panas terhadap daya kecambah leguminosa centro (centrosema pubescens) dan siratro (macroptilium atropurpureum). Jurnal Agrinimal. 2(1): 26-29.

Purdyaningsih, E. 2015. Penggunaan Kertas Merang Dan Kertas Cd Sebagai Alternatif Media Pengujian Daya Berkecambah Benih Wijen (Sesamum indicum L). Balai Besar Perbenihan dan Proteksi Tanaman Perkebunan. Surabaya.

Rahayu, A.D. 2015. Pengamatan uji daya berkecambah, optimalisasi substrat perkecambahan dan pematahan dormansi benih kecipir (Psophocarpus tetragonolobus (L.) DC). [Skripsi]. Institut Pertanian Bogor. Bogor.

Rahmasyahraini. 2008. Studi periode pengujian daya berkecambah serta pengaruh perlakuan benih dan jenis media perkecambahan pada benih jarak pagar. [Skripsi]. Institut Pertanian Bogor. Bogor.

Sadjad, S. 1980. Panduan Pembinaan Mutu Benih Tanaman Kehutanan di Indonesia. Institut Pertanian Bogor. Bogor.

Towaha, Rusli. 2010. Potensi Biji Turi untuk Substitusi Kedelai. Gramedia. Jakarta.

Widhityarini, D., M.W. Suryadi, P. Aziz. 2011. Pematahan dormansi benih tanjung (Mimusops elengi L.) dengan skarifikasi dan perendaman kalium nitrat. Fakultas Pertanian. Universitas Gajah Mada. Yogyakarta.

Yuniarty, N., D.F. Djaman. 2015. Teknik pematahan dormansi untuk mempercepat perkecambahan benih kourbaril (Hymenaea corbaril). Dalam Prosiding Seminar Nasional Masyarakat Biodiversitas Indonesia. September 2016. 1(6):1433-1437. 